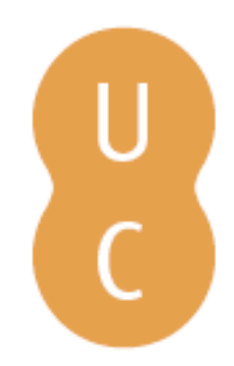

\title{
nommalina
}

\section{Simulating the effectiveness of prescribed burning at altering wildfire behaviour in Tasmania}

Autor(es): $\quad$ Furlaud, J. M.; Williamson, G. J.; Bowman, D. M. J. S.

Publicado por: Imprensa da Universidade de Coimbra

URL

persistente: URI:http://hdl.handle.net/10316.2/44656

DOI: $\quad$ DOI:https://doi.org/10.14195/978-989-26-16-506_139

Accessed : $\quad$ 26-Apr-2023 04:51:58

A navegação consulta e descarregamento dos títulos inseridos nas Bibliotecas Digitais UC Digitalis, UC Pombalina e UC Impactum, pressupõem a aceitação plena e sem reservas dos Termos e Condições de Uso destas Bibliotecas Digitais, disponíveis em https://digitalis.uc.pt/pt-pt/termos.

Conforme exposto nos referidos Termos e Condições de Uso, o descarregamento de títulos de acesso restrito requer uma licença válida de autorização devendo o utilizador aceder ao(s) documento(s) a partir de um endereço de IP da instituição detentora da supramencionada licença.

Ao utilizador é apenas permitido o descarregamento para uso pessoal, pelo que o emprego do(s) título(s) descarregado(s) para outro fim, designadamente comercial, carece de autorização do respetivo autor ou editor da obra.

Na medida em que todas as obras da UC Digitalis se encontram protegidas pelo Código do Direito de Autor e Direitos Conexos e demais legislação aplicável, toda a cópia, parcial ou total, deste documento, nos casos em que é legalmente admitida, deverá conter ou fazer-se acompanhar por este aviso.

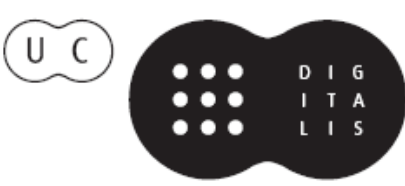




\section{ADVANCES IN}

\section{FOREST FIRE RESEARCH}

\section{8}

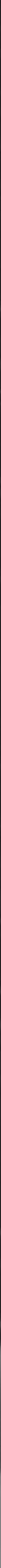


Short contribution - Fire Risk Management

Simulating the effectiveness of prescribed burning at altering wildfire behaviour in Tasmania

\author{
J. M. Furlaud*, G. J. Williamson and D. M. J. S. Bowman \\ School of Biological Sciences, University of Tasmania, Hobart, Tasmania, Australia, \\ \{james.furlaud@utas.edu.au*\}
}

\begin{abstract}
Prescribed burning is a widely accepted wildfire hazard reduction technique; however, knowledge of its effectiveness remains limited. To address this, we employ simulations of a widely used fire behaviour model across the ecologically diverse Australian island state of Tasmania. We simulate three broad scenarios: (1) no fuel treatment, (2) a maximal treatment, with the most possible prescribed burning within ecological constraints, and (3) 12 hypothetically implementable state-wide prescribed-burning plans. In all simulations, we standardised fire-weather inputs to represent regionally typical dangerous fire-weather conditions. Statistical modelling showed that an unrealistically large maximal treatment scenario could reduce fire intensity in three flammable vegetation types, and reduce fire probability in almost every vegetation type. However, leverage analysis of the 12 more-realistic implementable plans indicated that such prescribed burning would have only a minimal effect, if any, on fire extent and that none of these prescribed-burning plans substantially reduced fire intensity. The study highlights that prescribed burning can theoretically mitigate wildfire, but that an unrealistically large area would need to be treated to affect fire behaviour across the island. Rather, optimisation of prescribed burning requires careful landscape design at the local scale. Such designs should be based on improved fire behaviour modelling, empirical measurement of fuels and analysis of actual wildfires. Simulation modelling showed that an unrealistically large-scale prescribedburning program across Tasmania would be necessary to reduce wildfire extent and intensity under dangerous fire-weather conditions. By contrast, more feasible, but geographically constrained, broad-scale prescribedburning plans had substantially reduced effects on area burnt and fire intensity. This study highlights the need for targeted localised fuel treatments rather than broad-scale prescribed burning.
\end{abstract}

Keywords: prescribed burning, dry eucalypt forests, eucalypt forests, fire behaviour model, fire management, fire weather, fuel reduction, fuel treatment, leverage, sedgelands, temperate rainforests, wet eucalypt forests

\title{
1. Introduction
}

Prescribed burning is a widely accepted wildfire hazard reduction technique, however, knowledge of its effectiveness remains limited. Prescribed burning is designed to reduce fuel loads in flammable areas across a landscape, which in turn reduces the probability of wildfires encountering high fuel load areas. This should result in a reduction of both the extent and intensity of wildfire across a landscape. The effectiveness of prescribed burning at reducing the extent of wildfire has been quantified using the metric leverage: defined as the reduction in area burnt by wildfires resulting from one unit increase in area treated with prescribed burning. However, prescribed burns involve numerous potential negative social and ecological side effects. Therefore, understanding the trade-offs between the effectiveness of prescribed burning, particularly among different vegetation types, and its drawbacks is crucial.

\section{Methods}

To better understand these trade-offs, we employ simulations of the Phoenix Rapidfire model, a fire behaviour model that is widely used throughout southeast Australia. It is based on the McArthur Mk5 forest and CSIRO grassland fire behaviour models and calculates fire spread as a function of fuels, weather and topography. We simulated 62 series of 11,059 fires across the ecologically diverse island 
of Tasmania. Even though the Phoenix model was built for forests and grasslands, it has been adapted to Tasmania using empirically derived fuel accumulation curves for each vegetation type. For each series of simulations, we simulated a different fuel treatment plan, each of which falls under one of three broad treatment scenarios: a) no fuel treatment, b) an unrealistic maximal treatment, with the most prescribed burning possible within ecological and social constraints, and c) 12 more realistic implementable prescribed burning plans. In all simulations, we distributed ignitions uniformly and standardised fire weather inputs to represent typical dangerous fire weather conditions (i.e. the 9999. $5^{\text {th }}$ percentile McArthur Forest Fire Danger Index (FFDI)) for each of 45 meteorological regions in Tasmania. It should be noted that, due to Tasmania's diverse climate, this fire weather simplification did not substantially constrain the range of FFDI values used in the analysis (8.7-38).

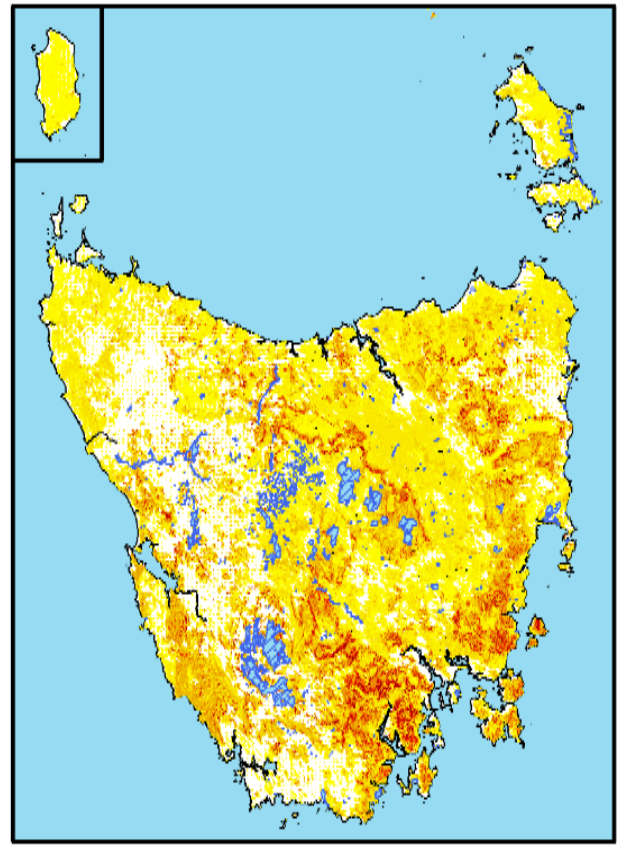

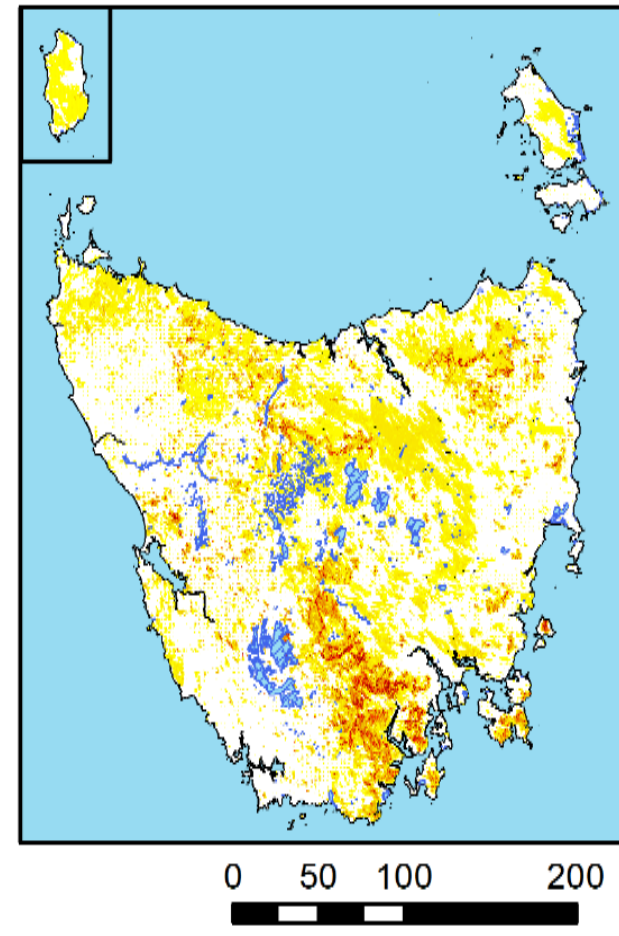

Kilometers
(a)
(b)

(a)

Figure 1 - Geographic patterns of maximum simulated fire intensities in Tasmania with (a) no fuel treatment scenario and (b) a maximal prescribed burning scenario in which all treatable fuels were burnt state-wide .

\section{Results \& Discussion}

We analysed the maximum simulated fire intensity under the null and maximal treatments qualitatively, using maps, and quantitatively, using generalised linear modelling (GLMs). The maps revealed distinct geographic patterns relating to vegetation, region, and terrain, and suggested that a maximal prescribed burning treatment substantially reduced both the extent and intensity of wildfire (Figure 1). The GLMs confirmed that maximal prescribed burning can reduce fire probability in almost every vegetation type, regardless of whether or not the vegetation was subject to treatment. However the GLMs also clarified that maximal prescribed burning can only reduce fire intensity in the three vegetation types which were extensively treated. Meanwhile, the 12 implementable prescribed burning plans were considerably less effective than the maximal scenario at reducing fire extent and intensity in all vegetation types. These implementable plans exhibited leverage in four vegetation types: dry eucalypt forest (leverage: 0.28 ), native grassland (0.3), native scrub (0.2), and non-eucalypt forest (0.24) (Figure 2), suggesting these plans were roughly half as effective as the maximal scenario. 
Additionally, our estimates of overall reductions in maximum intensity resulting from one hectare of prescribed burning (i.e. leverage intensity) were negligible for all vegetation types. These results suggest that intensive levels of prescribed burning are required to significantly alter fire activity, and that hypothetical plans that more closely reflect those implementable by fire managers will have little impact at an island-wide scale.

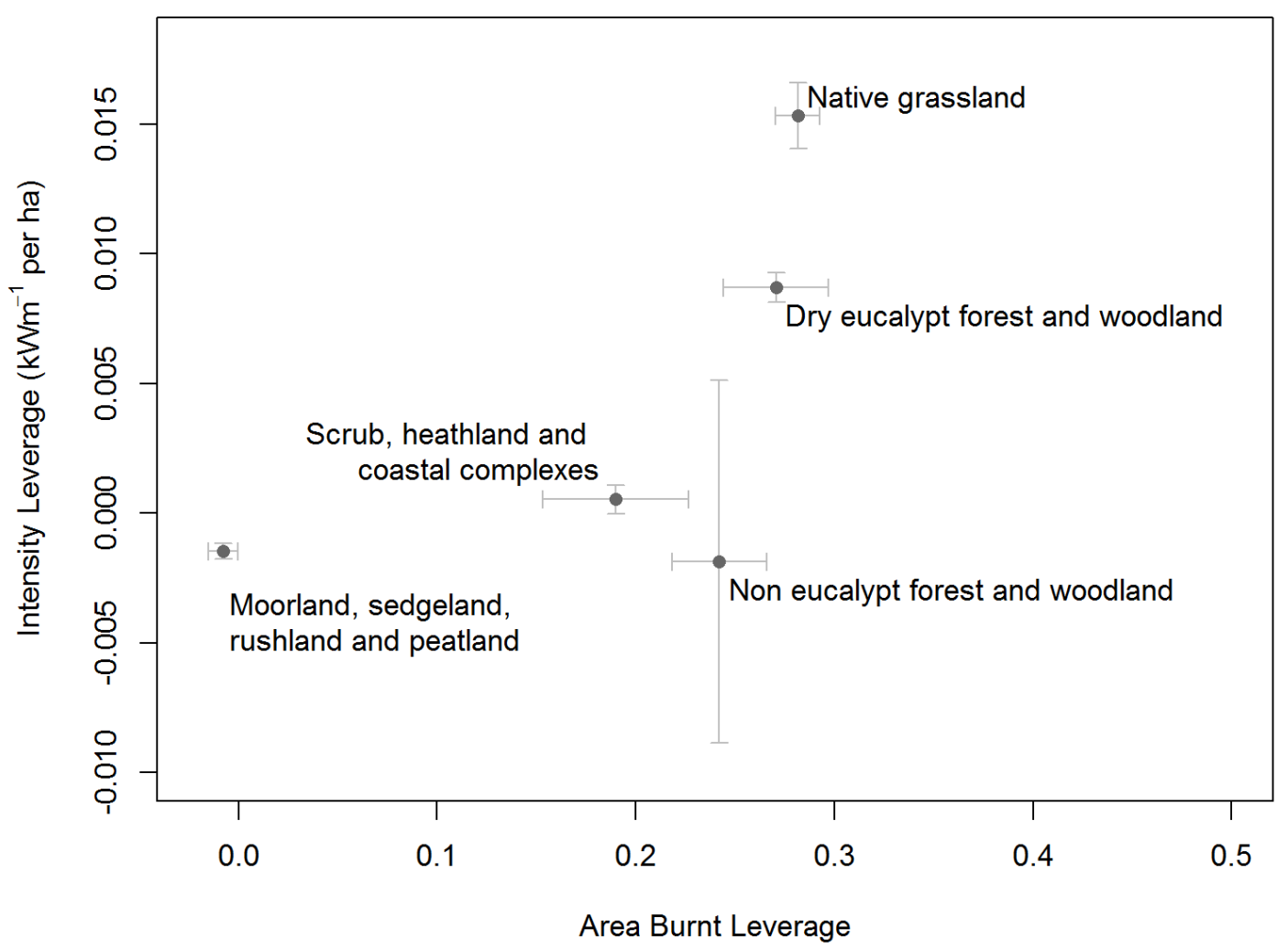

Figure 2 - Ordination of estimated area burnt leverage and intensity leverage (bars represent one standard error) for each of the Tasmanian vegetation types under the implementable prescribed burning scenarios (12 treatments). Area burnt leverage is defined as the reduction in unplanned burning resulting from one unit area treated through planned burning. Intensity leverage is defined as the reduction in intensity in $\mathrm{kW} / \mathrm{m}$ per hectare treated.

This study highlights that prescribed burning can be effective for wildfire mitigation, but suggests that an unrealistically large area would need to be treated with prescribed burning to meaningfully alter fire behaviour across the island of Tasmania. We argue that this indicates a need for intensive, but localised, fuel treatments. Therefore, we conclude that optimisation of prescribed burning requires careful landscape design based on improved fire behaviour modelling, empirical measurement of fuels, and analysis of actual wildfires. 